Note

\section{Metal Specificities on Induction and Binding Affinities of Heavy Metal-binding Complexes in Water Hyacinth Root Tissues}

\section{Masayuki FuJita and Kouhei NAKANO}

\author{
Laboratory of Food Hygienics, \\ Faculty of Agriculture, Kagawa University, \\ Miki-cho, Kida-gun, Kagawa 761-07, Japan
}

Received January 29, 1988

Various kinds of Cd-containing complexes a metallothionein-like $\mathrm{Cd}$-binding protein have been found in higher plants. ${ }^{1 \sim 5)}$ Fujita, ${ }^{6)}$ however, reported that a Cdbinding complex, which resembles fission yeast $\mathrm{Cd}-\mathrm{BP} 1^{7)}$ consisting of cadystin peptides $\left[(\gamma-\mathrm{Glu}-\mathrm{Cys})_{n}\right.$-Gly $n=2$ and $3]^{8)}$ rather than mammalian Cd-thionein, was formed in the root tissues of water hyacinth (Eichhornia crassipes Solms) when the plant was cultivated in a Cd-containing medium. Fujita and Kawanishi ${ }^{9)}$ also reported that fission yeast $\mathrm{Cd}-\mathrm{BP} 1$-like $\mathrm{Cd}$-binding complexes were formed in the root tissues of various kinds of vegetables. On the other hand, Grill et al. ${ }^{10)}$ independently demonstrated that diverse plant cells absorbed various heavy metals and produced a series of phytochelatins, $(\gamma-\mathrm{Glu}-\mathrm{Cys})_{n}$-Gly $n=3 \sim 7$, which could form heavy metal-binding complexes. Recently, they ${ }^{11)}$ reported the details of their biosynthesis using plant cell suspension cultures.

In this paper, we report that the metal specificities on induction and binding affinities of heavy metal-binding complexes, constructed with cadystin peptides and/or phytochelatins, in the root tissues of water hyacinth are extremely specific to $\mathrm{Cd}$, and also suggest that the complexes might not be important for the metabolism of $\mathrm{Zn}$, differing from in case of mammalian metallothioneins.

Water hyacinths were cultivated in a greenhouse in Yoshimura's solution. ${ }^{12)}$ The plants were cultivated in the nutrient solution supplemented with $10 \mu \mathrm{M}$ of a metal salt for 7 days, except that the $\mathrm{Ag}, \mathrm{Fe}$ and $\mathrm{Mn}$ salts were supplemented at 20,30 and $43 \mu \mathrm{M}$, respectively. After cultivation, the roots were washed with tap water and then with deionized water. The roots were homogenized with 1.5-fold tissue weight of $25 \mathrm{~mm}$ Tris- $\mathrm{HCl}$ buffer, $\mathrm{pH} 8.0$, containing $0.25 \mathrm{M}$ sucrose, $1 \%(\mathrm{w} / \mathrm{v})$ ascorbate and $10 \%$ (w/v) Polyclar AT in a pestle and mortar. The homogenate was squeezed through two layers of nylor cloth and the filtrate was centrifuged at $22,000 \times g$ for $1 \mathrm{hr}$. The supernatant was designated as the tissue extract.

A Sephadex G-50 column $(4 \times 59 \mathrm{~cm})$ equilibrated with $10 \mathrm{~mm}$ Tris- $\mathrm{HCl}$ buffer, $\mathrm{pH} 8.0$, containing $100 \mathrm{~mm} \mathrm{KCl}$ was used to fractionate the tissue extract. The tissue extract, $40 \mathrm{ml}$, was applied to the column and fractions of $6.3 \mathrm{ml}$ each were collected. The extract was eluted with the buffer used to equilibrate the column and the void volume was determined using Blue Dextran.

Heavy metals were determined by atomic absorption analysis with a Hitachi 308 Two Wavelength Atomic Absorption Spectrophotometer.

In order to determine whether the induction of heavy metal-binding complexes in water hyacinth root tissues is specific to $\mathrm{Cd}$ or not, plants were grown in mediums containing various kinds of heavy metals and each tissue extract was applied to a Sephadex G-50 column (Table I). In the case of $\mathrm{Cd}$, all $\mathrm{Cd}$ contained in the tissue extract was eluted at around fraction 65 as a heavy metal-binding complex (mol wt of about 4,000), as previously reported by Fujita and Kawanishi. ${ }^{13)}$ In the cases of both $\mathrm{Cu}$ and $\mathrm{Pb}$, though a small amount of each corresponding heavy metal-binding complex was detected at around fraction 65 , most of the metal was eluted as the free ion (around fraction 93; bed volume fraction), a nonspecific proteinbinding form (around fraction 18; void volume fraction) and an unknown form (around fraction 81), which was found only in the case of $\mathrm{Cu}$ (data not shown). In the cases of other heavy metals, all of the metal eluted was fractionated as the free ion and a nonspecific protein-binding form.

Grill et al. ${ }^{11)}$ reported that various heavy metals, such as $\mathrm{Cu}, \mathrm{Zn}$ and $\mathrm{Ni}$, induced the synthesis of phytochelatins (including cadystin peptides), components of plant heavy metal-binding complexes, in cell suspension culture of a high plant, Rauvolfia serpentina, but the concentrations of the heavy metals used in their experiment were much higher

Table 1. Formation of Metal-binding

Complexes in Water Hyacinth

Root Tissues TREated With Various Heavy Metals

\begin{tabular}{|c|c|c|c|}
\hline \multicolumn{2}{|c|}{ Treatment } & \multicolumn{2}{|c|}{$\begin{array}{l}\text { In Fraction } 65 \text { eluted from } \\
\text { a Sephadex G-50 column }\end{array}$} \\
\hline Heavy metal & $\begin{array}{l}\text { Concentration } \\
(\mu \mathrm{M})\end{array}$ & $A_{265}^{a}$ & Heavy metal \\
\hline $\mathrm{Cd}$ & 10 & ++ & ++ \\
\hline $\mathrm{Cu}$ & 10 & + & + \\
\hline $\mathrm{Zn}$ & 10 & - & - \\
\hline $\mathrm{Ni}$ & 10 & - & - \\
\hline $\mathrm{Ag}$ & 20 & - & - \\
\hline $\mathrm{Hg}$ & 10 & - & - \\
\hline $\mathrm{Pb}$ & 10 & - & + \\
\hline $\mathrm{Fe}$ & 30 & - & - \\
\hline $\mathrm{Mn}$ & 43.2 & - & - \\
\hline $\mathrm{Bi}$ & 10 & - & - \\
\hline
\end{tabular}

a $A_{265}$ is due to the heavy metal-mercaptide chromophore. 
than those in ours. Their heavy metal concentrations caused some serious morphological damage to the water hyacinth roots and leaves, when no heavy metal-binding complexes occurred during the treatments. In order to determine whether or not other heavy metals than Cd have the ability to act as a trigger for the synthesis of phytochelatins in water hyacinth root tissues or binding affinity to them, though they can induce phytochelatins like $\mathrm{Cd}$, an equimolar amount of $\mathrm{Cd}$ was added to the tissue extract of water hyacinth root treated with each heavy metal, and the mixture was applied to the Sephadex G-50 column. No new Cd-binding complex was detected in place of the free $\mathrm{Cd}$ ion on the chromatogram. These results suggest that the synthesis and formation of heavy metal-binding complexes is physiologically very specific to $\mathrm{Cd}$ in water hyacinth root tissues. Maita et al. ${ }^{14)}$ recently reported that a complex was specifically induced by $\mathrm{Cd}$ in a unicellular phytoplankton, Phaeodactylum tricornutum. Therefore, the induction of heavy metal-binding complexes might be specific to $\mathrm{Cd}$ not only in multicellular systems, such as tissues and/or organs, but also in single cell systems, though Grill et al. ${ }^{11.15)}$ reported that various heavy metals induced some phytochelatins in fission yeast and suspension cultures of $R$. serpentina. As described above, the Sephadex G-50 column chromatogram of water hyacinth root tissue treated with $\mathrm{Cu}$ showed a peak of an unknown $\mathrm{Cu}$ form between those of the Cu-binding complex and the free $\mathrm{Cu}$ ion. When this peak fraction was rechromatographed in the same way, all the $\mathrm{Cu}$ was eluted as the free ion. When an appropriate amount of $\mathrm{Cu}$ was added to the extract of the water hyacinth root tissues not treated with a heavy metal, $\mathrm{Cu}$ was eluted as the free ion on Sephadex G-50 column chromatography. As the amount of $\mathrm{Cu}$ used was gradually decreased, the free $\mathrm{Cu}$ ion first disappeared and then the unknown $\mathrm{Cu}$ peak disappeared, though the $\mathrm{Cu}$-binding complex remained. It remains to be determined whether the unknown form of $\mathrm{Cu}$ is due to weak interaction with the Cu-binding complex itself or an unknown low molecular weight substance induced by $\mathrm{Cu}$.

The transport of $\mathrm{Cd}, \mathrm{Cu}$ and $\mathrm{Zn}$ from the roots to leaves of water hyacinth was examined for 6 days. Though the rate of absorption of $\mathrm{Cu}$ from the cultivation medium into the plant was apparently much greater than those of $\mathrm{Cd}$ and $\mathrm{Zn}$, the metal content ratios, root to leaf, for $\mathrm{Cd}, \mathrm{Cu}$ and $\mathrm{Zn}$ were $6.8,5.3$ and 3.7 , respectively. This result led to the conclusion that the formation of a heavy metalbinding complex might play a role in the suppression of the diffusion of the heavy metal among tissues and/or organs.

In order to examine the substitution ability of heavy metals, as to the water hyacinth Cd-binding complex, an extract of root tissues of the plant treated with $\mathrm{Cd}$ was incubated with another heavy metal at $4 \circ \mathrm{C}$ for $1 \mathrm{hr}$ and then applied to the Sephadex G-50 column as described above (Table II). Copper could substitute for all the $\mathrm{Cd}$ in the Cd-binding complex, in an equimolar ratio. $\mathrm{Hg}$ and $\mathrm{Ag}$ could also be substituted but the others including $\mathrm{Zn}$ and
Table II. Substitution Ability of Heavy Metals as to the Water Hyacinth Cd-binding Complex

\begin{tabular}{|c|c|c|}
\hline \multirow{2}{*}{ Additive } & \multicolumn{2}{|c|}{$\begin{array}{l}\text { In Fraction } 65 \text { eluted from } \\
\text { a Sephadex G-50 column }\end{array}$} \\
\hline & $A_{265^{a}}$ & Substitution of metals \\
\hline $\mathrm{Cu}$ & + & + \\
\hline $\mathrm{Zn}$ & + & - \\
\hline $\mathrm{Ni}$ & + & - \\
\hline $\mathrm{Ag}$ & + & + \\
\hline $\mathrm{Hg}$ & - & + \\
\hline $\mathrm{Pb}$ & + & - \\
\hline $\mathrm{Fe}$ & + & - \\
\hline $\mathrm{Mn}$ & + & - \\
\hline $\mathrm{Bi}$ & + & - \\
\hline
\end{tabular}

Ni could not at all. These characteristics seem to resemble to those of mammalian metallothioneins, except that the binding affinity of $\mathrm{Zn}$ was too weak.

\section{REFERENCES}

1) M. Bartolf, E. Brennan and C. A. Price, Plant Physiol., 66, 438 (1980).

2) H. J. Weigel and H. J. Jäger, Plant Physiol., 65, 480 (1980).

3) G. J. Wagner and M. M. Trotter, Plant Physiol., 69, 804 (1982).

4) M. Kaneta, H. Hikichi, S. Endo and N. Sugiyama, Agric. Biol. Chem., 47, 417 (1983).

5) W. E. Rauser, Plant Physiol., 74, 1025 (1984).

6) M. Fujita, Plant Cell Physiol, 26, 295 (1985).

7) A. Murasugi, C. Wada and Y. Hayashi, Biochem. Biophys, Res. Commun., 103, 1021 (1981).

8) N. Kondo, M. Isobe, K. Imai and T. Goto, Agric. Biol. Chem., 49, 71 (1985).

9) M. Fujita and T. Kawanishi, Plant Cell Physiol., 28, 379 (1987)

10) E. Grill, E. L. Winnacker and M. H. Zenk, Science, 230, 674 (1985).

11) E. Grill, E. L. Winnacker and M. H. Zenk, Proc. Natl. Acad. Sci. U.S.A., 84, 439 (1987).

12) K. Tatsuyama, H. Egawa, H. Yamamoto and M. Nakamura, Zasso Kenkyu, 24, 206 (1979), in Japanese.

13) M. Fujita and T. Kawanishi, Plant Cell Physiol., 27, 1317 (1986).

14) Y. Maita, S. Kawaguchi and K. Tada, Abstracts of Papers, the International Symposium on Red Tides, Takamatsu, Japan, 1987, p. 58.

15) E. Grill, E. L. Winnacker and M. H. Zenk, FEBS Lett., 197, 115 (1986). 